\title{
The Nigerian Federalism: The Constitutionality Of The Local Government As A Federating Micro-Unit*
}

\author{
Godwin Okeke
}

\begin{abstract}
In one breath, the Constitution of the Federal Republic of Nigeria of 1999as amended recognizes the Local Government system as constituting a tier of government different from the Federal Government and the States Governments, thereby giving the impression of Nigeria as having a three-tier government; while in another breath, it devolves power only to the Federal and States Governments. This latter standing defeats the realization of the perfect ideals of true federalism. As it is presently, the Constitution recognizes the Local Government as an arm of government which maintains an account based on received allocation from the Federation Account and which office holders occupy offices based on being validly elected to those offices. The way forward, therefore, is to amend the said Constitution in order to provide a legal template on which the mission of getting the local government as an autonomous federating micro-unit will be accomplished.
\end{abstract}

\section{Introduction}

The Constitution of the Federal Republic of Nigeria, 1999 as amended (the 1999 Constitution), provides for 36 units of the Federation otherwise known as the 36 states of the federation ${ }^{1}$. The Federal Capital Territory, Abuja is also part of the federating units in Nigeria ${ }^{2}$. The word 'federation' means a union of states with a central power yielding a true national government possessing sovereignty both external and internal .Though definitions are often fraught with pitfalls because of their inability to encompass all forms of the particular concept or idea sought to be defined, they are inevitable. Generally, the concept of federalism relates to the division of power between a national government and a regional or state governments and sometimes, local governments. Such power may however be shared in various ways, sometimes with a stronger centre, or with a weaker centre which is often referred to as con-federalism.

\section{Federalism and the Sharing of Power}

Professor B.O. Nwabueze, in his book Federalism in Nigeria under the Presidential Constitution defined federalism as:

"an arrangement whereby powers of government within a country are shared between a national, country-wide government and a number of regionalized (i.e territorially localized) governments in such a way that each exists as a government separately and independently from others operating directly on persons and property within its territorial area, with a will of its own and its own apparatus for the conduct of its affairs, and with an authority in some matters exclusive of all others."

The sharing of power between the center and the components featured glaringly in the definition of 'federation'. The Constitution of the Federal Republic of Nigeria 1999 shares power between the Federal government, the state government and the local governments. The tiers of government under a federation are of considerable equality and independence. It is however, doubtful whether local governments in Nigeria possess the above features, i.e, equality and independence as state government in Nigeria possesses. Again the Nigerian Federation has, in the First Republic, been referred to as a Federation of unusual composition.

Hillarie Barnett in the book, Constitutional and Administrative Law, rightly observed that local government represents both a form of decentralization of power from central government and a basis for democracy; that local governments antecede central government by many centuries; that historically, local governments

*G.N. Okeke, B.Sc.; LL.B; LL.M; PhD, Reader, Faculty of Law Nnamdi Azikiwe University, Awka, Anambra State, Nigeria.; e-mail: okekegodwinn_40@yahoo.co.uk.

Sec. 3(1) provides that there shall be thirty six states in Nigeria, that is to say, Abia, Adamawa, Akwa-Ibom, Anambra, Bauchi, Bayelsa, Benue, Bornu, Cross River, Delta, Ebonyi, Edo, Ekiti, Enugu, Gombe, Imo, Jigawa, Kaduna, Kano, Kastina, Kebbi, Kogi, Kwara, Lagos, Nasarawa, Niger, Ogun, Ondo, Osun, Oyo, Plateau, Rivers, Sokoto, Taraba, Yobe, and Zamfara. Sec. 3(4), Sections 298,299. 
represented an early form therefore that the local government system in Nigeria should be improved upon and be made distinct from state entity for more meaningful and grass root development; that it has been observed that local authorities are subject to the whim of central government and that they do not exist in their own right and their activities may be curtailed by the enactment of government legislation.It is clearly captured in the above position that there is no strict separation of powers between the central government and the local government and at the same time reveals the need to devolve powers to local authorities 'so as to bring government nearer to the community it serves'.

In the First Republic, between 1960 to 1966, the local governments owed their very existence to the Regional Governments. However, the attempt to give the local government autonomous identity was made in 1979 by the 1979 Constitution when it was given a status almost making it a government distinct from that of a state.

\section{The Provision for the Local Government Structure in the 1999 Constitution}

The 1999 Constitution recognized the local government as arm of government by assigning some functions to it. It provides that the system of local government by democratically elected local government councils is under the Constitution guaranteed; and accordingly, the Government of every State shall, subject to section 8 of this Constitution, ensure their existence under a Law which provides for the establishment, structure, composition, finance and functions of such councils. The local government, therefore, is recognized by the 1999 Constitution, its status is not distinct from that of the state. This is because the 1999 Constitution provides that the person authorized by law to prescribe the area over which a local government council may exercise authority shall do so while having regard to communal common interests, traditional association and administrative convenience in order to ensure the existence of local governments under a law which provides for the establishment, structure, composition, finance and functions of local governments. In other words, there is no clear autonomy given to a local government; consequently, it cannot be said to be a federating unit as autonomous as the federal and state government in a federating relationship.

However, the creation of new local government area in Nigeria in 2005 generated a considerable degree of devastating heat in the Nigerian polity. The then Federal Government did not hide its feeling when it seized the allocation of fund due to some states over the issue of creation of additional local government area. The then Lagos State Government, in particular, went to court to challenge the action of the Federal Government. Despite the Supreme Court's ruling that the allocation due to Lagos State from the Federation Account should be released to the state, the Federal Governments continued to withhold the allocation. The problem was later settled politically and not legally. The constitutional provision on local government creation has raised an issue relating to whether the state government alone has the power to create new local governments and provided a breeding ground for controversy and conflict between the two levels of the executive arm of government as reflected in the above case.

It is not in any reasonable doubt that the states, under the 1999 Constitution, have control over local governments by ensuring "their existence under a law which provides for the establishment, structure, composition, finance and functions" of such local governments. Therefore, the establishment of local government councils is a sole function of a state government.

Nevertheless, it is provided by the Constitution to the effect that there shall be seven hundred and sixtyeight local government areas in Nigeria as shown in the second column of part 1 of the First Schedule to the 1999 Constitution and six areas councils as shown in part 11 of that Schedule.The above provision means that no additional local government can be created without altering the section of the Constitution to reflect the number of the existing local government councils in Nigeria. This cannot be legitimately done without involving the National Assembly whose functions do not only include law making and law repealing but also include law amendment which extends to the amendment of the Constitution.

The 1999 Constitution simply states that the establishment of local government councils shall be done by the states governments. The states are asked to see that the local governments that are already in existence (i.e, 768 local governments) are established local governments and that none of them should be allowed to 'die' but rather, that all of them should be allowed to 'exist' structurally, financially and functionally, and in response to the need for new local government councils, create them while keeping to the constitutional procedure. The contemplation of the 1999 Constitution of Nigeria as it relates to creation of the local government councils in Nigeria is that states could create new local government councils subject to the concurring alteration of the Constitution by the National Assembly to reflect the addition in the number of local governments in Nigeria.

The ignorance of the above position is radiantly reflected in the creation of new local government councils in Nigeria in 2005 by some state Governors without recourse to the National Assembly, on the strong belief that they were acting within the bounds of their constitutional rights. The consequence of this was a strong opposition by the Federal Government which stoutly rejected the newly created local government councils and 'ordered' the 'erring' Governors to revert back to the to the status quo in relation to the number of the local 
government councils within their states as recognized by the 1999 Constitution. This was complied with in principle but in practice, the newly created local governments, in some cases, where turned into development centres that share in the allocation of resources with the existing local government councils for an even and better grass root development, an innovation considered as a spring board to more rural development by the states that adopted this unpopular stategy.

In bringing to the fore the inferior position assigned to the local government system in the Nigerian federalism, the Supreme Court in the case of Attorney-General of Ondo State v. Attorney General of the Federctinn 35 Ors, held that unlike the federal and state governments, the local governments do not have the constitutional backing, either in section 7 or in the Fourth Schedule of the 1999 Constitution to legislate against corruption. Therefore, the local governments are not equal with the federal and state governments as reflected in the degree of limitation in handling certain matters. Impliedly, the local government councils are not fully recognized as constituting a third tier of the federating units in Nigeria.

The dilemma associated with local government's creation and management on one hand and the status of local government councils as to whether or not they constitute the third-tier of government in Nigeria on the other hand could be overcome by the provision of the 1999 Constitution with the necessary amendments. However, the peculiarity of the 1999 Constitution is in conspicuously providing for a local government that is distinct from the Federal and State governments structure and assigning some functions to it which is listed in the Fourth Schedule. The inherent assumption underlying the above functions is that the 1999 constitution carved out the local government as an entity different from both the Federal and State governments. This position is glaringly reflected in the sharing of revenue allocation as provides for in the said Constitution which states that any amount standing to the credit of the Federation Account shall be distributed among the Federal, State Governments and Local governments councils in each state on such terms and in such manner as may be prescribed by the National Assembly.

The constitutional highlighting and underlining of political entities, Federal Government', 'State Government' and 'Local Government Councils' show clearly that the intendment of the 1999 Constitution is for Nigeria to have three-tiers of government. In other words that Constitution contemplates a more viable local government system than that which is presently operated passively in practical reality.

It does appear from all indications that the autonomy of Local Government Councils as envisaged in the 1999 Constitution is being watered down by the states. For instance, the establishment of a joint account between a state and the local government councils within its area of jurisdiction as provided by the Constitution could provide an opportunity for some States Governors to divert local government funds to personal accounts. The local government councils are thus left without proper funding and being in an inferior position going by political consideration to their state government, could do nothing other than wait for the time of their liberation or deliverance by means of a constitutional amendment in Nigeria.

\section{The Relevance of the Local Government System in Nigeria}

The local government is government at the grass roots. It is a basic government, near to the people and so localized in order to meet the basic social and economic needs of the beneficiaries - the local people. The local people by spatial arrangement are farther from the centre and nearer to the state. The local government is like a cell; while state government, like a tissue and the Federal Government, like an organ in a general system of administration in Nigeria. Each of these component parts in a system of administration provides essential services to the people.

T. Eddison states in relation to local government that:

"there can be no dispute that the effect of local government (and other levels and scales of government also) is intervention, intervention in the sense that it causes things to happen which may not otherwise happen or, on the other hand prevent things happening which may otherwise happen .... The very moment we accept local government as an institution we accept the fact that its effect will be intervention in the 'natural' order of things. The issue, then, is not whether or not local government should intervene - its very existence ensures that, but the degree to which it should intervene."

The impact of local government on the community is so crucial in the determination of whether it is relevant or irrelevant. Where it has no intervention approach - an avenue through which problems are either solved or prevented, its existence is called to question or its relevance subjected to doubt. What follows next would be a cell for its abolition. However, in a situation where the relevance of local government is strongly established, any call for the abolition of this essential tier of government will amount to nothing other than a mere political tool to maneuver it out of existence and hijack the fund accruing to it by the administration of state. Such unpopular tool is ineffective, the usage of which results to agitation and anarchy.

In relation to the responsibility of local government, Derek Senior states that: 
"Local government has a general responsibility for the well-being of the communities it represents; its concern is not confined to the discharge of the duties imposed on it by parliament. It must seek to promote community well-being in all its aspects-economic as well as social, cultural as well as physical- whether or not it has a statutory duty in relation to any particular aspect. And in discharging its statutory duties, it must put the general well-being of the local community before sectional interest of the central government department that is nationally responsible for the functions concerned."

From the foregoing, it is deducible that the essential nature of local governments is without any form of reasonable doubt. One form of government or the other is indispensable in every human association. A government recognized by law has a legal backing and legal functions. These functions are geared towards both intervention and well beings of the people. Local governments possess the above characteristics. Intervention functions of local government in Nigeria are in the following form:

(i) naming of roads and streets and numbering of houses;

(ii) registration of births, deaths and marriages;

(iii) establishment and maintenance of cemeteries, burial ground and homes for destitutes and firms;

(iv) establishment, maintenance and regulation of slaughter houses, slaughter slabs, markets, motor parks and public conveniences

(v) control and regulation of outdoor advertising, hoarding, movement and keeping of pets of all descriptions, shops, kiosks, restaurants, bakeries and other places of sale of food to the public and laundries.

(vi) the provision and maintenance of primary, adult and vocational education;

(vii) the development of agriculture and natural resources, other than the exploitation of minerals;

(viii) the provision and maintenance of health services.

The above intervention functions are so essential that without them, there would be confusion, frustration and riot which destabilize social cohesion and mutual co-habitation. It also leads to retardation of the rate of progress and even development. It is pertinent to state at this point that from the nature of the functions, for any government to carry them out, it must be closer to the people. The Federal and State Government have serious limitations if they are drafted into intervening and hijacking the above functions in order to provide adequately the felt needs which the functions are to address. The wellbeing functions increase the degree of the functional necessity of local governments to a significant level thereby justifying its existence. Any serious draw back noticed in the administration of local government could water down the importance of this system of administration.

\section{Local Government Council Area of Authority under the 1999 Constitution}

Local government council is a creation of the 1999 Constitution and as such, it derives its authority from the law. The 1999 Constitution provides that the person authorized by law to prescribe the area over which a local government council may exercise authority shall:

(a) define such area as clearly as practicable, and

(b) ensure, to the extent to which it may be reasonably justifiable, that in defining such area regard is paid to:

(i) the common interest of the community in thearea,

(ii) traditional association of the community, and

(iii) administrative convenience.

However, in defining an area of authority for local government councils, regard should be had to the fact that the number of autonomous communities and the population of people within a new local government area are not significantly below or above average as it relates to the number of communities and population of people in existing local government areas all over Nigeria. Otherwise, a situation would be created whereby some local government councils would have a relatively small coverage areas and this would result to over funding of such councils at the expense of those councils that have bigger coverage area. This is not justifiable especially when considered in the context of intervention approach and maintenance of the well-being of people by local government councils. A major consequence of the above imbalance is that it promotes uneven development. The 1999 constitution provides that:

"It shall be the duty of a local government council within the state to participate in economic planning and development of the area referred to in subsection (2) of this section and to this end an economic planning bound shall be established by law enacted by the House of Assembly of the State".

The type of economic development envisaged by the above provision cannot be achieved only through planning on a state-wide level where bogus local government area is assigned to a local government council to cover. In other to smoothly facilitate the transformation of the dream of local government economic 
development into an objective reality the local government area of authority should be reduced to manageable size on a uniform level all over the federation.

\section{Election as the Basis of Local Government Democracy in Nigeria}

Election generally is the forerunner to democracy. The 1999 constitution provides that the Government of a state shall ensure that every person who is entitled to vote or be voted for at an election to a House of Assembly shall have the right to vote or be voted for at an election to a local government council. From the foregoing, the contemplation of the Constitution is to the effect that the local government system in Nigeria shall be run by democratically elected officers. Elective positions to a local government council include that of the chairman of the local government council and councilors. The chairman represents the executive arm of government who oversees the administration of local government council with the supervisory councilors appointed by him; while the councilors constitute the legislative arm of local government administration.

In the case of Lawrence Alake V. Michael Shaaho \& 4 ors, the Court of Appeal held, inter alia, that an election can only be deemed to have been concluded when by virtue of paragraph 20 to 39 of schedule 4 to the Local Government (Basic Constitutional and Transitional Provisions) Decree No.36 of 1998, when the following have taken place:

(a) accreditation

(b) conduct of poll

(c) counting of votes

(d) collation of results

(e) signing of result forms; and

(f) publication of results

Therefore, for a chairman of any local government council or a councilors to emerge as provided by the Constitution, he must have contested for that position in a poll which must be conclusive and favourable to him by virtue of his being declared as having won in the poll going by the election results published by the Independent National Electoral Commission (INEC).Moreover, for a candidate that vies for the office of a local government council chairman or that of a councilor in any local government to be declared as winner the said election must be free and fair.

In Mrs. Patricia Ngwu V. Emmanuel Mba \& 2 ors, the Court of Appeal held, inter alia, that a victory, achieved through the instrumentality of election rigging is a farce and pyrrhic one and that such a victory is often created as in the instant case by electoral officers who should not be trusted with serious assignment relating to electoral process. Rigging in an election is an open manifestation of distrust of the candidate vying for an elective post by no person other than himself. It is an infantile approach to a matter as serious and demanding as that of an election of the people's representatives. Where evidence of such practice is available, it constitutes the foundation on which an election petition is made in the Nigerian Legal System.

In Mohammed G. Mustapha V. Alhaji Ibrahim Bulma \& 3 ors, the Court of Appeal held, inter alia, that by virtue of paragraph 5(3) (a) of the $5^{\text {th }}$ schedule to the Local Government (Basic Constitutional and Transitional Provisions) Decree No. 36 of 1996 an election petition shall conclude with a prayer or prayers, as for instance, that the petitioner or one of the petitioners be declared validly elected or returned, having polled the majority of lawful votes cast at the election or that the election may be declared nullified, as the case may be.

It is to be noted that the 1999 Constitution has made a way forward for Local Government Administration in Nigeria by providing for democratically elected officers - the people representatives to man such administration. Rigging and other unlawful acts, sabotage this noble objective and as things are presently in Nigeria, the courts are living up to expectation by the cancellation of elections results which are products of rigging in order to stem the tide of the rising wave of charlatans rigging their ways through to the esteemed elective posts in local government councils.

\section{Local Government Funding: Reflective of a Three-tier System of Government}

The 1999 Constitution in a show of regard for the existence of local government councils and desire to sustain its existence makes allowances for the allocation of fund to the councils. The councils get their major fund from an account prescribed by the Constitution to service the tiers of governments, i.e, Federal, State, and Local Governments which is known as the Federation Account into which all revenues, with some exceptions collected by the government of the federation are paid into. The state governments are constitutionally empowered to collect the fund for themselves and on behalf of their local government councils and then pay the local government councils in their states such proportion of the collected fund on such terms and in such manner as may be prescribed by the National Assembly. This financial co-habitation between states and local government councils is solemnized in the inner chamber of joint account set up by the Constitution to accommodate such fund. 
Other means of fund generation for local government councils include fund generated from shops, kiosks, tenement rates, domestic animal license, bicycles, trucks, canoe, wheel barrow, cart charges or licenses, burial ground charges, out-door advertising charges, slaughters slab fees, fees for registration of births, deaths and marriages, radio, television licenses, and liquor license.

As regards the Federation Account, the Supreme Court of Nigeria listed the local government as one of the three beneficiaries of the Federation Account, and 'concluded that any form of first line charges are illegal According to records, before the resource control suit between some states and the federal government decides by the Supreme Court, the following was the revenue allocation formula:

$\begin{array}{llll}\text { (i) } & \text { Federal Government } & = & 48.5 \% \\ \text { (ii) } & \text { State Government } & = & 24.0 \% \\ \text { (iii) } & \text { Local Government } & = & 20 \% \\ \text { (iv) } & \text { Special Funds }= & 7.5 \% & \end{array}$

The decision of the Supreme Court relates to the fact that there should be only three beneficiaries to the Federation Account namely the federal government, the state government and local government consequently; the federal government came out with a revenue sharing arrangement involving the three tiers of government as follows:

$\begin{array}{llll}\text { (i) } & \text { Federal government } & = & 52.68 \% \\ \text { (ii) } & \text { States government } & = & 26.72 \% \\ \text { (iii) } & \text { Local government } & = & 20.60 \%\end{array}$

It has been observed, in relation to the Federation Account that the Central Bank of Nigeria (CBN) is the custodian of the Federation Account; the Accountant-General of the Federation under the instrumentality of the Federation Account Allocation Committee (FAAC) operates the Account while the Revenue Mobilization Allocation and Fiscal Commission monitors accruals into and disbursements from the Account. The Federation Account therefore is the major financial tube that waters the economy of the three tiers of government. It is an account which contains the centrally collected high yielding taxes in Nigeria for disbursement to the beneficiaries. From the foregoing, the financial oxygen necessary to keep alive the local government has been principal supplied by the Constitution. Where the local government system losses breath, the cause is not constitutional; the cause should then be man-made. In other words, the cause is artificial. This underscores the importance of local government system which is as old as Nigeria and dates as far back as 1900 when it featured as the Native Authority under the indirect rule system of the British Colonial Administration.

\section{Conclusion}

Nigeria practices federalism, the concept of federation supports the sharing of powers between the tiers of government in existence. One essentially feature of federalism is the autonomy of each of the component unit or level of government. The place of the local government councils in the government of Nigeria is guaranteed by the 1999 Constitution.

Local government administration is a form of decentralization of power in order to meet the needs of the native inhabitants of local government areas and others who reside in such a locality. The need for a separate identity of local government from state government has been conceived by the 1999 Constitution, hence, its highlighting the federating units as comprising the Federal Government, State government and Local government Councils. In practice, local government is made to operate as part of state government administration. To justify this position, the Local Government Civil Service Commission floated by state government administers the affairs of local government councils in a state. This practice enabled by laws of a State House of Assembly defeats the intention of the Constitution to make the local government a third-tier of government in a federal structure maintained in Nigeria political arrangement having its own chief executive and legislative; functions and revenue; area of coverage and council.

It is pertinent to state at this point that the intendment of the 1999 Constitution for providing for elected officers of local government is to ensure democracy and non- interference in the local government administration. In order to give the local government its proper place in Nigeria there is need to safeguard the existence of a local government and protect it from that predatory tendencies of a state government in the form of removal by the state of the local government chairman and replacing the elected chief executive of the local government with caretaker committee or sole administrator; making unilateral deductions from the State Joint Local Government Account; politicizing career jobs in Local government councils in order to accommodate politicians in career jobs at the expense of experts manning carrier officers in Local government councils and disregard of seniority as basis of retaining or putting people to man those offices.

It is submitted that enhancing the local government administration constitutes essential panacea to the cure of the Niger Delta crisis in Nigeria. The Local inhabitants of the area have remained sad over the neglect of 
government, at whatever level, to their plight of poverty, lack of basic infrastructure and general neglect and this was made more painful to them because of the fact that a significant percentage of the amount of crude oil produced in Nigeria is from that area.

It is further submitted that in order to give it a proper place in the third tier arrangement of government in Nigeria, the local government system should be made through constitutional arrangement to have its own judiciary just as the Federal and State Governments have theirs. Moreover, the local government system, as a tier of legitimate government should be allowed, through a constitutional amendment, to get the allocation accruing to them directly from the Federation Account. 